\title{
THE TOPOGRAPHY OF RELIGION IN ARCHAIC IONIA
}

\author{
ARKAIK IONIA'DA DIN TOPOGRAFYASI
}

\section{KENAN EREN*}

\begin{abstract}
Continuing archaeological research at the major sanctuaries of Ionia has revealed detailed information concerning their chronology and spatial organization. The location and the history of these sanctuaries has been investigated based upon a model that places the city at the centre of the territory. According to this model, the location of these sanctuaries has been classified under the categories: urban, semi-urban and extra-urban. However, an alternative approach to this model can be through recognising that the history of these sanctuaries was shaped by their interaction with both the physical and human geography. Applying this alternative model, one could go on to examine the impact of the "human geography" on the choice of the particular location and the spatial organization of these sanctuaries. Thus, in Ionia since the sea provides the principal communication surface between different fragments of the region, access to the sea is a common feature of many Ionian sanctuaries and it seems between the Bronze Age and the Archaic Period there was a repeated similarity in the religious responses to the topography of the environment.
\end{abstract}

Keywords: Archaic Period • Ionia $\bullet$ Sanctuary • Topography $\bullet$ Sea
Öz: Ionia kutsal alanlarında uzun zamandır devam eden araştırmalar, bu alanların kronolojisi ve mekansal organizasyonu hakkında detaylı bilgiler sağlamıştır. Bu kutsal alanların konumu ve tarihçeleri ise genelde kenti merkeze alan bir modele göre incelenmiştir. Bu model, kutsal alanların konumlarını kent merkezinde, kent merkezine yakın veya merkezin $\mathrm{d}_{1}$ şında gibi kategorilerle ilişkili olarak değerlendirmektedir. Buna alternatif bir model ise, kutsal alanların tarihçesinin fiziksel ve beşeri coğrafyayla kurdukları ilişkiye göre şekillendiğini kabul etmek yoluyla oluşturulabilir. Bu model, "beşeri coğrafyanın” kutsal alanların yer seçimi ve mekânsal organizasyonuna etkisini anlamaya özel bir önem verecektir. Ionia'daki Arkaik Dönem kutsal alanları bu gözle incelendiğinde, denizin bölgenin farklı kısımları arasında iletişimi sağlamanın en önemli yolu olduğu ve kutsal alanların sıklıkla denizle ve deniz yollarıyla ilişkili konumlarda bulunduğu gözlemlenebilmektedir. Anlaşılan coğrafi çevreyle kurulan bu ilişki, Arkaik Dönem dinsel topografyasının Bronz Çağı kalıntılarıyla belirli bir devamlılık göstermesinin de nedenini oluşturmaktadır.

Anahtar Kelimeler: Arkaik Dönem • Ionia • Kutsal Alan • Topografya $•$ Deniz

Archaeological research in Ionia has been undertaken for almost two centuries to date, and all recent findings have shown that many important sanctuaries adorned the region in the Archaic period. From the VII ${ }^{\text {th }}$ century BC onwards several new sanctuaries were built and many existing Iron Age sanctuaries were renovated and altered. Therefore the examination of the spatial distribution of cultic spaces within the Ionian region in the Geometric and Archaic periods may provide us with important indications concerning what exactly influenced the selection of places of worship within a defined geographical context. It follows that one must also ask both when and why worship at these sites became both physically and socially visible ${ }^{1}$.

Scholars have often shown curiosity about the spatial recontextualizing of cult-places while they

* Yrd. Doç. Dr., Mimar Sinan Fine Arts University, Department of Archaeology, İstanbul. kenaneren@msgsu.edu.tr

1 Polignac $1995^{2}, 29$. 
remain mainly interested in the political and cultural, rather than the productive landscape ${ }^{2}$. Therefore many studies that aim to understand the position of the sanctuaries within a city's territory often try to establish a link between the location of sanctuaries and the larger development of the Greek polis. The increase in the number of sanctuaries built from $750 \mathrm{BC}$ onwards, and the simultaneous establishment of city walls and other major public spaces within them, has been interpreted as emblematic of the emergence of the Greek polis ${ }^{3}$. In this context, Polignac's seminal book " $L a$ Naissance de la Cité Grecque" presents a generally accepted model in which the city lies at the centre of the territory and its public and sacred spaces help to articulate the relationship between different parts of the polis ${ }^{4}$. Within a hierarchy such as this, the city's sanctuaries are divided into three categories: urban, peri-urban, or extra-urban. This categorization is often an indispensable criterion for examining the organization of these sacred spaces. It should be also noted that a century of abundant excavations which have concentrated mainly on the centres of cities seems to strength this perception of the central position of the centre ${ }^{5}$.

However, it might be useful to ask whether it is possible to adopt a different reading of space by replacing the central position of the city with another location, such as a sanctuary or a territorial boundary. It is therefore important to question the traditional analysis that defines the city as the most influential political organization within a city-state, and instead to focus upon the territories' unique places and those structures with which these communities might also have sought to define themselves. The book by C. Morgan shows a good example of what an alternative approach might $b^{6}$. In this context, the balance between local identities and the broader concept of geography is particularly important and regional overviews are useful for understanding the long-term strategies of the city-states' territorial ambitions. Accordingly, a topological study of the sanctuaries requires the evaluation of different interactions and networks that helps to define the creation of space for religious activities.

Therefore, my aim in this article is to investigate the position of Ionian sanctuaries within the broader geography of Archaic Ionia in order to understand how geography influenced the choice of sacred cult spaces. This investigation does not, however, take into account a deterministic relation between the topography and cult activities. Instead, I will try to consider the influence of the human uses of the environment upon the selection of religious spaces. Thus, a systematic review of the available evidence for cult activity in Archaic Ionia with particular reference to the geographical positioning of that activity in relation to the natural topography or to other landscape phenomena (e.g. harbours) will be required.

The main Ionian cities were located by the coast where there were a number of bays available for maritime activities. Indeed, access to the sea was a very important feature of Ionian cities. In this context, the sea and natural ports in the region are an important factor to consider and are likely to have influenced the selection of locations for the establishment of sanctuaries. Maritime activities were

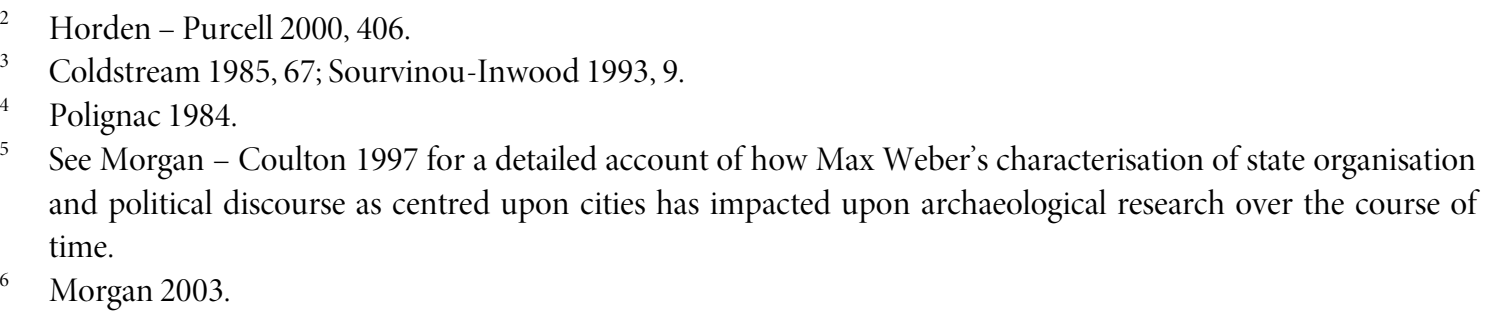


always very important in the Mediterranean, and in this period a cultic topography was developed in parallel to the developing maritime culture ${ }^{7}$. In this article, the investigation of the influence of the sea and sea networks on the spatial distribution of the sanctuaries of Ionia is the focus.

A second aim is to investigate the presence of Bronze Age remains in some important Ionian sanctuaries. The evidence for Bronze Age activity (not necessarily cultic) at some sites will be discussed in the second part of the article in order to understand if there was repetition due to the similarity of religious responses to the environment in different periods, and the extent to which it was necessary take into account pre-existing cult places in the development of sanctuary sites in the Archaic period. Thus, it seems necessary to re-evaluate the archaeological data in order to question the impact of the local geography-topography upon the continuous use of a site, particularly in the period between the Bronze Age and the Geometric Period.

\section{Sanctuaries and the Sea: Connectivity in Ionia in the Archaic Period}

Physical geography has always been integrated into the various studies that deal with the location of sanctuaries. Many studies also show that the locations chosen for sanctuaries in the region are often significant for the specific cults and deities that are worshipped there ${ }^{8}$. It can be argued then that the local geography and religion influenced certain choices made by the polis, although it remains difficult to theorize a deterministic relationship between religion and the landscape ${ }^{9}$. On the other hand, it is clear that social interactions also constitute the basis for the structuring of space, and therefore, topography and climate might not be the most important factors in articulating a territorial conceptualization ${ }^{10}$.

A closer look at the locations of Ionian sanctuaries may be more helpful in understanding this relationship between geography and religion (Fig. 1). As Greaves has pointed out, Ionia is a land of mountains and valleys, and the region consists of mountains aligned east-west that extend out into the sea, forming peninsulas and, beyond these, islands ${ }^{11}$. The main Ionian cities were situated on these peninsulas and islands, and almost all of them have good harbours (Kolophon presents an exception to this feature with its access to the sea obtained via Notion). On the other hand, this geographically fragmented terrain also creates small island-like pockets, each controlled by a central authority. Since the east-west divides between the different valleys are the most striking feature of the Ionian landscape, north-south communication by land seems to be extremely difficult, while the valley bottoms extending in an east-west direction provide more suitable prospects for transport and for strong land communication ${ }^{12}$. The most important road situated on the north-south axis was probably that between the Meander Valley and the Hermos Valley. This route linked the plains of Hermos and Meander, even though it seems more appropriate to the transport of smaller objects due to the road's rugged nature ${ }^{13}$ (Fig. 2).

Thus, one cannot underestimate the importance of the sea's role as a facilitator between the site

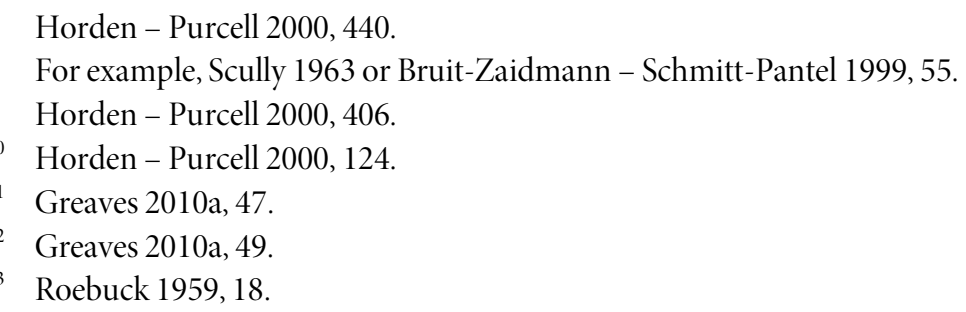




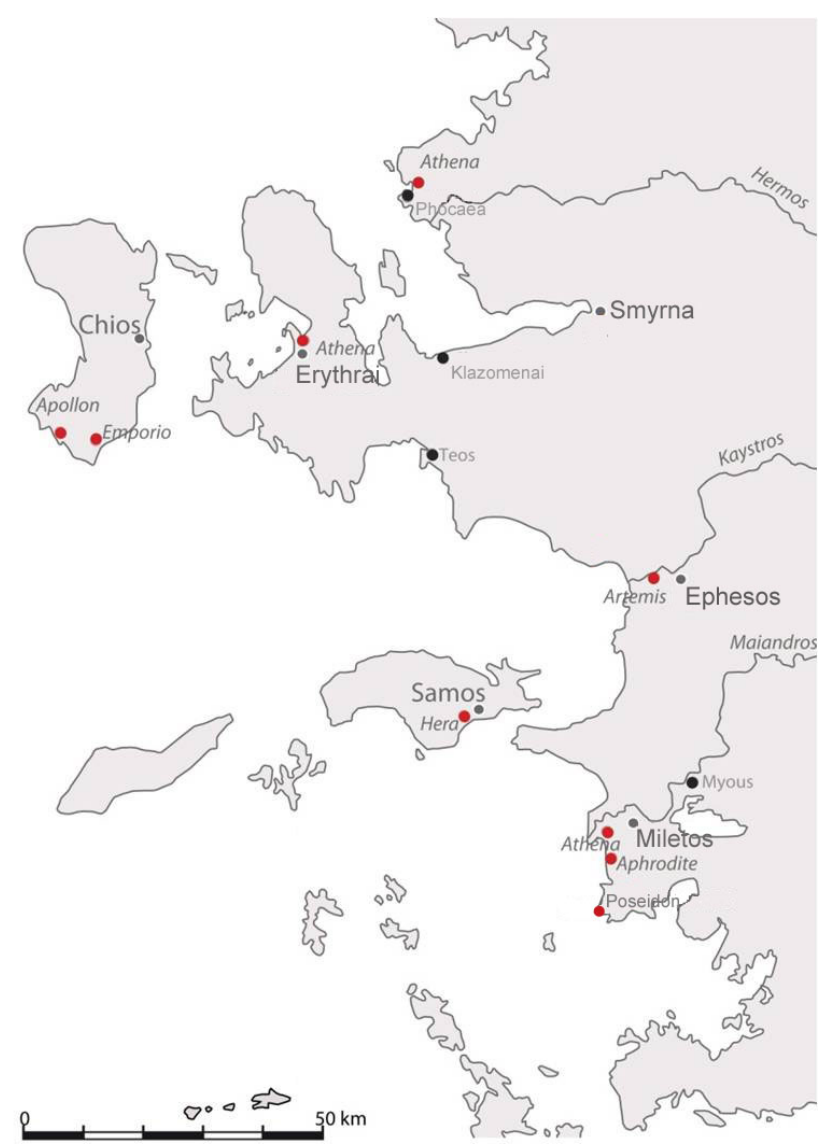

Fig. 1.The Main Cities and Sanctuaries of Ionia in the Archaic Period

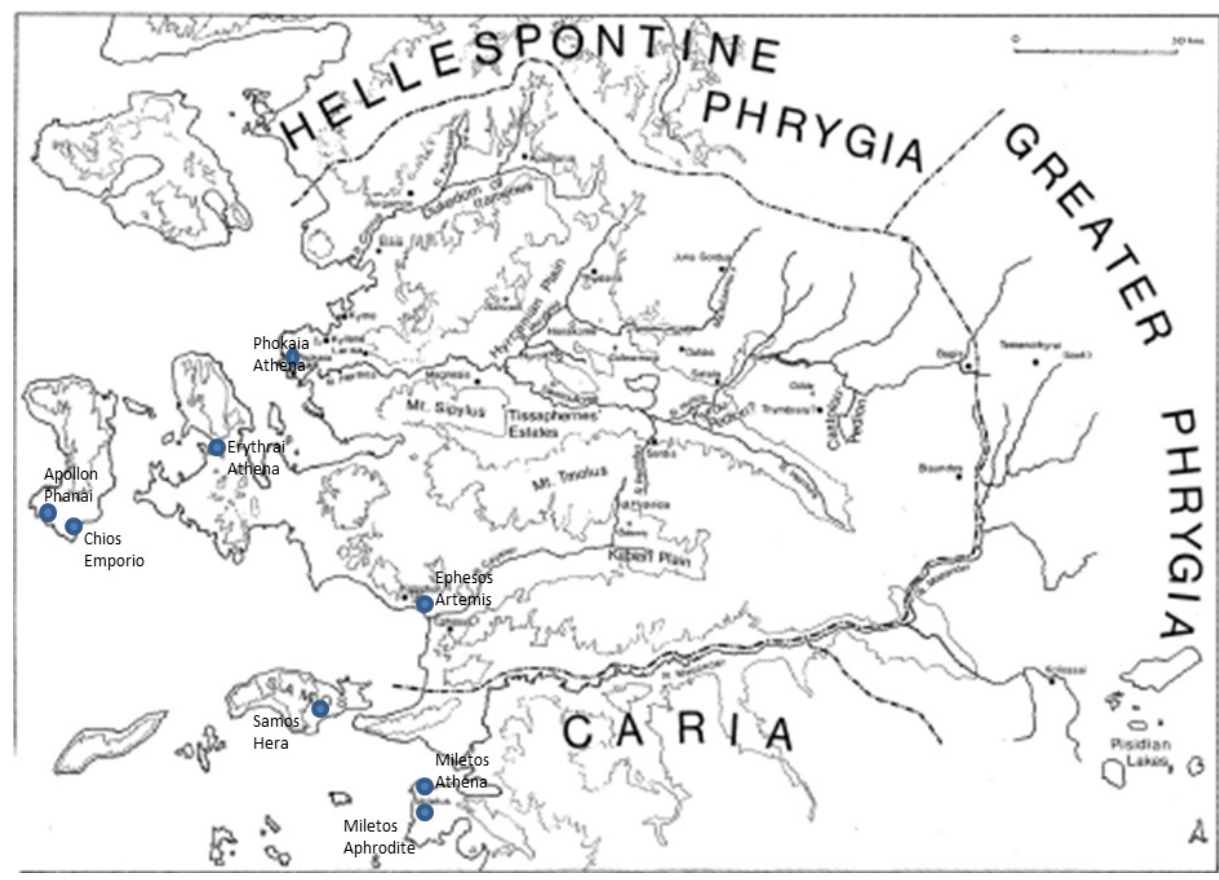

Fig. 2. Ionian Sanctuaries and Ionian Geography 
of this fragmented landscape ${ }^{14}$. The most important Ionian sanctuaries are unsurprisingly in direct communication with the sea, which appears to be a critical factor in many cases. On the other hand, the rocky coasts of the region offer very few shelters for ships in case of emergency and natural ports or secured bays on the coast are relatively rare $^{15}$. In this context, the sea and the location of natural ports are a very important factor in the selection of the locations of the establishment of sanctuaries. The growing maritime culture of the Aegean, especially from around $800 \mathrm{BC}$ is well known, and one can observe a decided growth in the presence of cults on the Aegean coast during this period as well ${ }^{16}$. If we evaluate the sanctuary locations in relation to the known sailing routes, several important factors become evident.

The visibility of these sanctuaries from the sea was likely to have been an important factor and many were used as seamarks for ships sailing in the coastal zone. Coastal navigation was essential in the Archaic period, and fixed points in the natural landscape that were visible to sailors provided indispensable seamarks for maritime communications ${ }^{17}$. Because of this, many religious structures were built on or near to these natural features along local sailing routes. One may include in this category the sanctuary of Aphrodite Oikous in Miletos (Fig. 3). This sanctuary was established on a hill

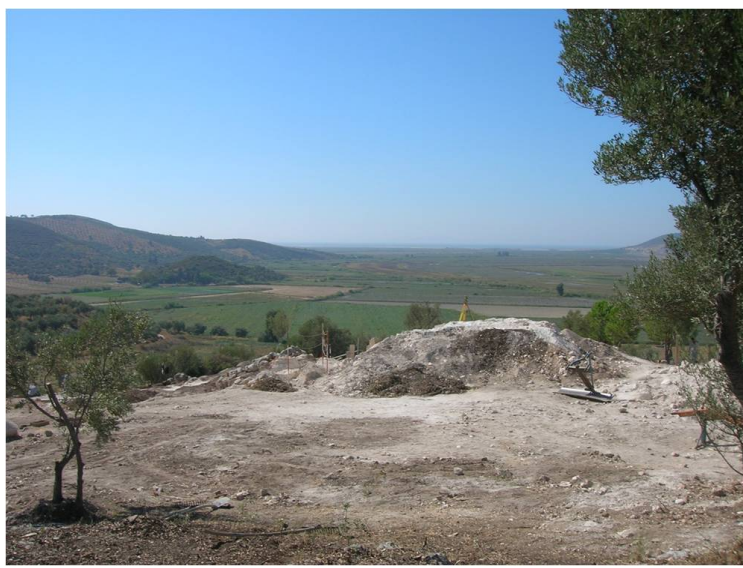

Fig. 3. The Position of the Miletos Aphrodite Sanctuary (Photo: Kenan Eren) (modern name Zeytintepe) $2 \mathrm{~km}$ to the west of Miletos. The sanctuary and the nearby suburb were the first seamarks visible from ships that were sailing towards Miletos ${ }^{18}$. The early structure dates from the VII ${ }^{\text {th }}$ century BC and has been identified as the first phase of the temple. However, it is also possible that this early structure was used for ritual meals. The early structure was destroyed towards the end of the $\mathrm{VI}^{\text {th }}$ century to allow for the creation of a monumental temple ${ }^{19}$. As Greaves has already pointed out, Aphrodite was perceived as a sea goddess in Miletos and its colonies. Literary, epigraphic and archaeological evidence of the sacrifice of sea creatures in Zeytintepe also support this opinion ${ }^{20}$. The presence of thousands of ceramic fragments, probably used in the public feasts, forces one to consider that the sanctuary was frequently visited by the Milesians, mostly at the end of the VII ${ }^{\text {th }}$ and the first half of the VI ${ }^{\text {th }}$ century ${ }^{21}$. One should also mention that the sanctuary of Aphrodite reveals a large variety of votive gifts from the East. Faience objects, terracotta and limestone statues from Cyprus, and amulets and

14 Greaves 2010a, 66.

15 Greaves 2010a, 55.

16 Polignac 1994, 6.

17 Horden - Purcell 2000, 126-140.

18 Gans 1991, 137; Senff 2006, 169. Gans underlines that even though Kalabaktepe (the acropolis of Archaic Miletos) has a higher elevation; Zeytintepe is more "visible" from the sea.

19 2003, 3; see also Senff - Heinz 1997, 114.

20 Greaves 2010a, 43; see also Greaves 2004.

21 Senff 2003, 17-20. 


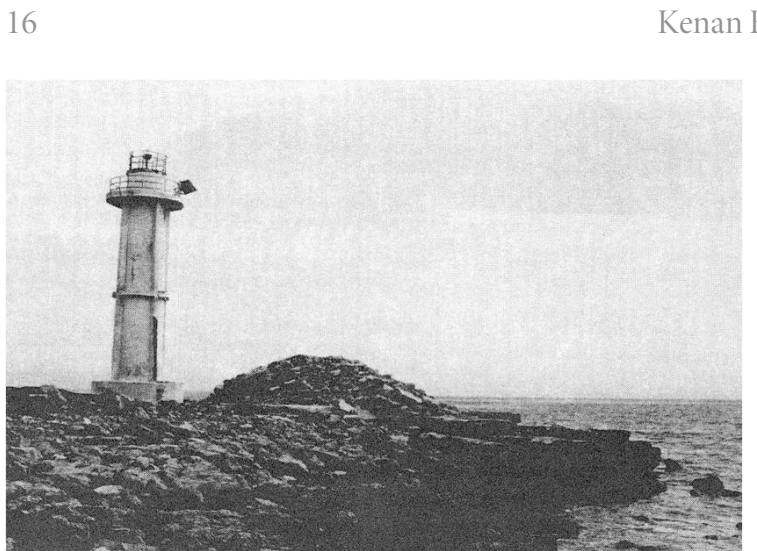

Fig. 4.The Altar of Poseidon on Cape Monodendri (Greaves 2000a, fig.7)

scarabs from Egypt form the majority of the votive gifts ${ }^{22}$.

Another interesting example of the seamark function of a sanctuary site is at Miletos. The Altar of Poseidon on Cape Monodendri (Tekağaç Burnu) exists in a clear relation to the sea (Fig. 4). The monumental altar was made from white marble with dimensions of 11 to 20 metres $^{23}$. It must have been clearly visible from the sea much like a lighthouse ${ }^{24}$. In fact, this zone is one of the most dangerous sections of the coast in the region and its location also indicates the entrance to Panormos where the sanctuary of Apollo at Didyma was located. Although it is the case that a sacred road linked Miletos to Didyma, it seems that the sea route was the most popular means of reaching Didyma, thus rendering Panormos the main port providing access to the sanctuary of Apollo ${ }^{25}$.

In this context one may also consider those sanctuaries that are situated in the harbours of major cities. Ionian cities were situated near bays and were usually oriented towards the sea. As a consequence, one may observe the existence of many other sanctuaries both oriented towards the sea and visible from it. However, these sanctuaries are usually situated at the summit of the city's acropolis and it is difficult to interpret their location solely in terms of their relation to their visibility from the sea. Nonetheless, the relationship between the sanctuaries and the cities' harbours can neither be denied nor ignored.

The Harbour sanctuary of Emporio on Chios belongs to this group, even if we do not know the identity of the deity that was worshipped there. Boardman contends that the sanctuary was in use between the VII ${ }^{\text {th }}$ and $\mathrm{V}^{\text {th }}$ centuries $\mathrm{BC}^{26}$. The sanctuary consists of a series of terraces linked by a path to the port. Boardman also notes the presence of a settlement on the slopes of the hill behind the port that predates the XII ${ }^{\text {th }}$ century $\mathrm{BC}$, the remains of which were used in the construction of the harbour sanctuary ${ }^{27}$.

Another sanctuary, the sanctuary of Athena, was situated on the acropolis of Emporio. The first altar was constructed there in the VII ${ }^{\text {th }}$ century and a temple was added in the VI ${ }^{\text {th }}$ century, though it should be noted that the oldest objects from the sanctuary date from the VIII ${ }^{\text {th }}$ century BC ${ }^{28}$.

It seems important to underline that in the VII ${ }^{\text {th }}$ century, bronze arms and terracotta votive shields form the majority of the gifts in the sanctuary of Athena on the fortified acropolis. But, more significantly, almost all of the votive gifts from the sanctuary were produced within the local context. On the other hand, the harbour sanctuary of the Emporio presents an entirely different

\footnotetext{
Saint-Pierre 2005, 374.

Gerkan 1915, 465-466.

24 Greaves 2000a, 45-46.

25 Herda 2006, 350.

26 Boardman 1967, 62.

27 Boardman 1967, 52-97.

28 Boardman 1967, 34.
} 
picture. Almost all the votive gifts found in the sanctuary are imported objects from the East, most noteworthy of which are several fibulas, pins and belts from Phrygia ${ }^{29}$. Faience examples from Egypt and terracotta statues from Cyprus were also found in this sanctuary ${ }^{30}$.

Other sanctuaries in Miletos also appear to be situated in relation to the city's different harbours (Fig. 5). The sanctuary of Apollo Delphinion may be one such example. The sanctuary was situated near to the "Bay of Lion" and the so-called "Lion's Port" was the main harbour of the city in the Classical Period, although its use in the Archaic Period is not yet clear. In fact, this sector may have been underwater until the beginning of the $\mathrm{VI}^{\text {th }}$ century $\mathrm{BC}^{31}$. However, the presence of an Archaic sanctuary in this area was established through excavations in 1974, and it is known that the city's archives of the $\mathrm{VI}^{\text {th }}$ century $\mathrm{BC}$ were kept there $^{32}$. In the Archaic Period, we can assume

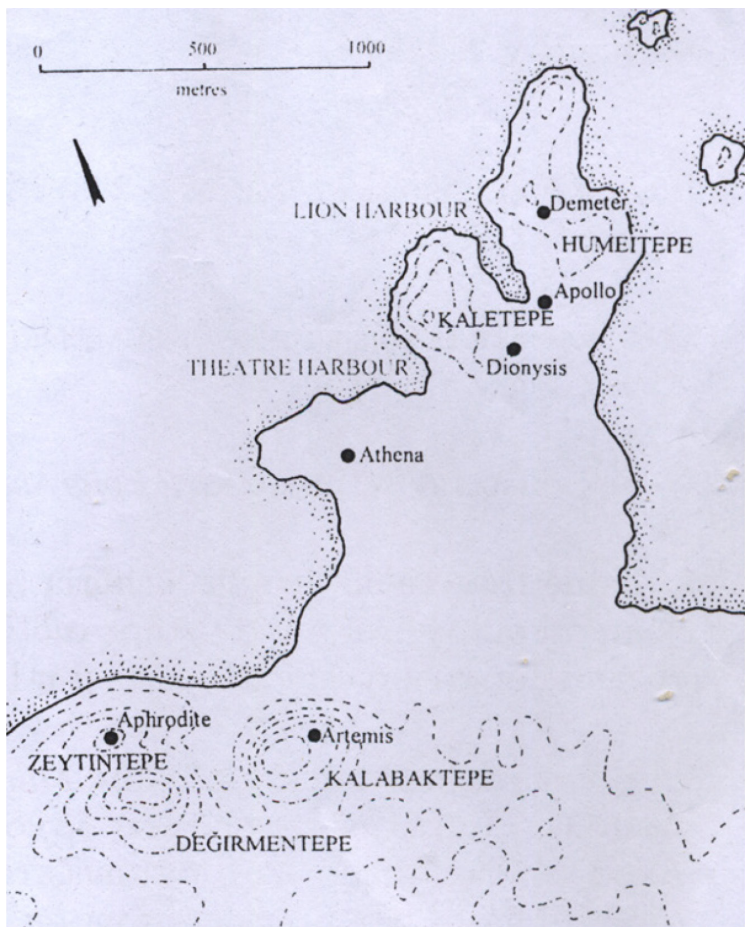

Fig. 5. The Archaic Sanctuaries in Miletus

(Greaves 2002, fig. 3.5) the existence of a large open area next to the sanctuary that would become the main agora of the city in the Classical Period ${ }^{33}$. In any case, this area would become the main port of the city beginning in the Classical Period.

A more interesting example is the sanctuary of Athena, situated on the so-called theatre harbour. It was built on top of the Mycenaean-Period city walls where there were also altars dating from the late Minoan IA and IB Period (1675/50-1490/70 BC). Apparently this area was the centre of the settlements in the Minoan and Mycenaean Periods ${ }^{34}$. In the sanctuary, the Geometric Period kultmal was a small oval shaped structure surrounded by a rectangular wall. A building with an inner colonnade was constructed at the end of the VII ${ }^{\text {th }}$ century BC, which was later replaced by a marble temple ${ }^{35}$. The gifts from the sanctuary are mostly metal objects. Bronze containers, cauldrons and tripods, as well as arms and armour form the main body of the votives ${ }^{36}$. The majority are imports from the East, especially from northern Syria. The small quantity of ceramics and the quality of the gifts may suggest that this sanctuary belonged to a small privileged community ${ }^{37}$.

Geophysical studies have shown that the harbour of Geometric and Archaic Miletos was very

29 Simon 1997, 132-133

30 Saint-Pierre 2005, 369.

31 Herda 2005, 253.

32 Senff 2006, 167; see also Herda 2005, 253-259.

33 Herda 2005, 291.

34 Niemeier - Niemeier 1997

35 Niemeier 1999, 396-409.

36 Held 2000, 80-85.

37 Eren 2015, 323. 
close to the sanctuary of Athena. Indeed, during the Geometric Period, Miletos was composed of two main settlements: the fortified citadel of Kalabaktepe and a settlement around the theatre harbour and the sanctuary of Athena ${ }^{38}$. Consequently it appears that during the Geometric Period, Miletos was a bipartite settlement and the harbour area provided a more open zone, while the fortified citadel in Kalabaktepe provided defence for the community ${ }^{39}$. A sanctuary dedicated to the patron goddess of the city, Artemis Kithone, existed on Kalabaktepe from the second half of the VIII $^{\text {th }}$ century onwards ${ }^{40}$.

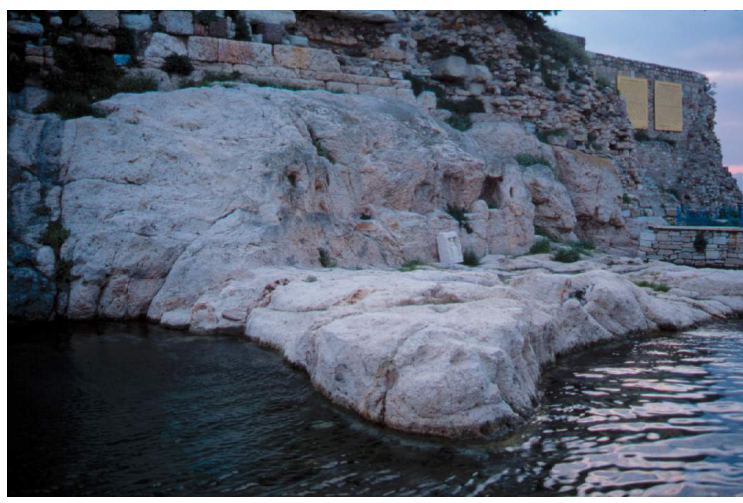

Fig. 6. Phokaia the Shrine to Cybele by the Sea (Photo: Kenan Eren)
Another example of a sanctuary built in relation to a city's harbour is at Phocaea. The acropolis of Phocaea is located on a terrace, which is the highest point of the peninsula. Here, two monumental temples of Athena were constructed one after the other, the first in the first half of the VI ${ }^{\text {th }}$ century and the second during the second half of the VI ${ }^{\text {th }}$ century BC. However, ceramic finds from beneath the foundation of the temple date to the VIII ${ }^{\text {th }}$ century $\mathrm{BC}^{41}$. There is also another shrine, probably dedicated to Cybele, built on the rocks beside the sea ${ }^{42}$. This shrine is located next to a wall along the port, which also served as the retaining wall for the sanctuary of Athena. The shrine is oriented towards the sea, and the only access to it was from the harbour. It seems that visitors had to use the sea to enter the sanctuary. It consisted of seven niches of different sizes, carved into the rock wall. Finds show that this shrine was built at the same time as the Temple of Athena (Fig. 6) ${ }^{43}$.

The sanctuary of Heracles in Erythrai is a final example that demonstrates this spatial relationship between sanctuary and harbour. Today archaeological information concerning the sanctuary is quite limited. Yet it is conceivable that it was situated behind the port of Erythrai while another temple dedicated to Athena was constructed on the acropolis of the city at the beginning of the VII ${ }^{\text {th }}$ century. This VII ${ }^{\text {th }}$ century temple was later replaced by a new temple, also dedicated to Athena, which was built sometime in the first half of the $\mathrm{VI}^{\text {th }}$ century $\mathrm{BC}^{44}$. In all cases, the foundation myths of the Heracles sanctuary emphasize his close association with the sea ${ }^{45}$. It is noteworthy that excavations in the Athena sanctuary at Erythrai have presented a rich variety of offerings of Phoenician, Egyptian, Cypriot, Corinthian and Rhodian origin, dated between 750 and 500 BC. In particular, a wide variety of Phoenician and Cypriot terracotta figurines dating from the VIII ${ }^{\text {th }}$ and VII ${ }^{\text {th }}$ centuries $^{46}$.

\footnotetext{
38 Treziny 2006, 245.

39 Greaves 2000b, 64-66.

40 Kerschner - Senff 1997, 122.

41 Özyiğit - Erdoğan 2000, 13.

42 Özyiğit - Erdoğan 2000, 21.

43 Özyiğit 1995, 431-432.

44 Akurgal 1979, 5.

45 Paus. VII. 5. 6-8

46 Bayburtluoğlu 1977, 3; see also Gültekin 1968.
} 
As shown by the examples of Miletos, Chios Emporia, and perhaps also Erythrai given above, it seems apparent that a model of spatial organization existed in Ionia. According to this model, a settlement was organized between two poles: a city centre on a hill with a fortification wall and another centre near the harbour where interactions with the outside world took place. The distribution of votive gifts seems to follow this model ${ }^{47}$. It is evident therefore that many of the most important sanctuaries of Ionia were built in direct relation to the sea, and their harbours assigned them a place within the Aegean maritime network. With this in mind, the locations of certain other sanctuaries deserve to be further investigated, beyond only local or regional analyses.

The sanctuary of Hera at Samos, the sanctuary of Artemis at Ephesos and the sanctuary of Apollon Phanai at Chios are three such examples from the Geometric and Archaic Periods ${ }^{48}$. In fact, all of these sanctuaries were established in close proximity to the main Aegean maritime routes. Furthermore, all of these cities feature inlets and harbours that have a good reputation for the anchorage of ships. Therefore, it is possible to assume that their importance grew in parallel with the increase in maritime activities that occurred there ${ }^{49}$.

The Samian Heraion is a prime example of a sanctuary established with a clear relationship to the sea, perhaps more so than any other sanctuary of this period. It was established at the end of the river Imbrassos, $8 \mathrm{~km}$ from Samos. The beach near the sanctuary was ideally suited to provide anchorage for ships. The architectural history of the sanctuary began with a Proto-Geometric altar, although beneath the altar some Mycenaean artefacts dating from the late Helladic IIIB/C Periods were also discovered ${ }^{50}$. In the IX ${ }^{\text {th }}$ century, the existence of a primitive naiskos is possible, and between the $\mathrm{X}^{\text {th }}$ and the VIII ${ }^{\text {th }}$ centuries BC, a series of altars had been erected in the sanctuary ${ }^{51}$. In addition, the most ancient temple of the sanctuary, the so-called "Hecatompedon" dates from the first half of the VII ${ }^{\text {th }}$ century ${ }^{52}$. The main entrance to the sanctuary was at the south end until the VII $^{\text {th }}$ century when a monumental stoa and a large artificial basin were constructed. Most of the votive offerings were found in this area ${ }^{53}$. Additionally, the existence of the seven springs is mentioned in the sanctuary ${ }^{54}$. It should be noted that in Samos, there are large quantities of offerings from different regions, the majority of which comes from the Orient, though almost every region of the Mediterranean is represented ${ }^{55}$. These various gifts were mostly offered during the VIII ${ }^{\text {th }}$ and VII $^{\text {th }}$ centuries BC while Greek goods dating from this period are almost non-existent in the sanctuary ${ }^{56}$. Samos Island was a particularly important port on the navigation routes of the Aegean Sea, and the Samos Heraion is an example of a sanctuary situated in the middle of the Aegean navigation network. It appears that the sanctuary's integration into these sailing networks was particularly im-

47 Simon 1997, 131-132.

48 Because of the accumulated alluvium, the coastline of the Ionian landscape has changed throughout history; see Greaves 2010a, 45-68 for a detailed account of these changes.

49 Polignac 1994, 6.

50 Buschlor - Schleif 1933, 146-150; Walter 1990, 21; see also Rupp 1983.

51 Buschlor - Schleif 1933, 146-150.

52 Mallwitz 1981, 623-631.

53 Kyrieleis 1993, 136.

54 Guettel-Cole 1988, 164.

55 See Brize 1997 for a detailed analysis of the gifts dating from the Geometric and Archaic periods.

56 Saint-Pierre $(2005,357)$ underlines that the quality and quantity of the foreign artefacts at the Heraion is unequalled in the Greek world. 
portant for the community of the sanctuary, perhaps in order to represent their own territorial ambitions. It seems that the main entrance to the Heraion faced the sea and during the VII ${ }^{\text {th }}$ century a second access point from the north was annexed to the building. Finally, in the first half of the $\mathrm{VI}^{\text {th }}$ century a monumental entrance along the road coming from Samos was constructed and the other entrances were then closed off ${ }^{57}$.

The Ephesian Artemision is another sanctuary established witha direct relation to the sea. Geophysical analysis has shown that until the end of the Hellenistic era, the sanctuary was on the seashore and had its own harbour, just a hundred metres west of the Artemision ${ }^{58}$. It appears that during the Geometric and Archaic Periods, Ephesos was organized into two fortified settlements, Panayırdağ and Ayasuluk. The Artemision stood between the two settlements and constitutes "the nucleus" of a dispersed settlement organization ${ }^{59}$.

A wall of the sanctuary, dated to the Mycenaean era, is the earliest trace of built architecture. In the Eastern part of the sanctuary, excavations also revealed a natural spring ${ }^{60}$. First a peripteros was constructed in the second half of the VIII ${ }^{\text {th }}$ century ${ }^{61}$. However, excavations revealed that during the $\mathrm{VII}^{\text {th }}$ century BC, a series of rectangular bases were dispersed throughout the sanctuary. Traces of sacrifices and the presence of votive gifts in the surrounding areas seem to show that these bases were used in cult activities. In the same period, a building with an apsidal plan was erected south of the peripteros. One should also note the construction of the limestone "Temple C" towards the end of the VII ${ }^{\text {th }}$ century, and the simultaneous construction of the marble hecatompedon. The presence of a multitude of cult structures suggests that a variety of cult activities were taking place in the sanctuary at the same time ${ }^{62}$. The construction of the monumental peripteros in the $\mathrm{VI}^{\text {th }}$ century seems to have ended this kind of cultural diversity in the sanctuary.

The Artemision at Ephesos had a very rich deposit of votive offerings, mostly jewellery and finely carved ornaments made of precious metals and of ivory. Phrygian and Lydian objects constitute a significant percentage of the offerings, while imports from the Near East and Egypt are relatively rare $^{63}$. The existence of a great number of Lydian ceramics and coins has been interpreted as evidence for the continuous presence of Lydians at the sanctuary. The difficulty in discerning the difference between Lydian artefacts and the copies of these made in the Ephesian workshops has been interpreted as evidence of a close relationship between Lydia and Ephesos ${ }^{64}$. According to Herodotos, Ephesos was the natural harbour of the Lydians ${ }^{65}$. Gifts that Croesus gave to the sanctuary, which are well described in the literature may also be interpreted within this context ${ }^{66}$.

In Chios, at the sanctuary of Apollon Phanai, the harbour also plays a central role. The sanctuary is located 300 metres from the shore upon a terrace, 8 metres above sea level; although in earlier

57 Duplouy 2006, 190-191.

58 Kraft et al. 2000, 185-186.

59 Treziny 2006, 243-245.

60 Bammer 1998, 41.

61 Bammer 1991, 73; 1993, 187.

62 Bammer 1991-92.

63 See Eren 2012 for a comparison of the gifts objects from the Samos Heraion and the EphesosArtemision.

64 Kerschner 2008, 229.

65 Hdt. VI. 54. 100.

66 Hdt. I. 26 and I. 92; see also Eren 2012, 92. 
periods it was situated directly on the shore. Due to its sheltered and protected harbour, the excavators believe that this sanctuary was also integrated into the Aegean maritime navigation routes ${ }^{67}$. Some Late Mycenaean figurines in addition to Proto-Geometric and Early Geometric ceramics have been found in the sanctuary although they are mixed with Late Geometric and Sub-Geometric finds as well ${ }^{68}$. The construction of terrace walls and a monumental staircase was part of a later phase of building in the VII ${ }^{\text {th }}$ century BC. With the new monumental entrance in the north, the sanctuary was connected to both the road coming from the harbour in the west and the road coming from the valley in the northeast, although the entrance from the sea remained the most important and prominent ${ }^{69}$. During the $\mathrm{VI}^{\text {th }}$ century, a limestone temple was constructed together with a new peribolos wall ${ }^{70}$.

All of these examples demonstrate that a connection with the sea influenced the spatial distribution of Ionian sanctuaries. One should underline that there are few surviving traces of the structural organization in the VIII ${ }^{\text {th }}$ century BC Ionian sanctuaries and the remaining terracotta statuary constitute the main evidence for cult activities in most cases. Sanctuaries of the geometric period were mainly in the form of terrace arrangement surrounded by a peribolos. On the other hand, many new sanctuaries appear in Ionia during the VII ${ }^{\text {th }}$ century BC The Heraion in particular presents a very detailed panorama of the evolution of a sanctuary through integration into the Mediterranean maritime networks which clearly had an effect on the variety and diversity of gifts employed in cult activities.

In sum, it is possible to observe in almost all of the Ionian sanctuaries, gifts/objects that show connections to the far reaches of the Mediterranean, which becomes significantly more common in ritual practice in the $\mathrm{VII}^{\text {th }}$ century $\mathrm{BC}^{71}$. Apparently, as Foxhall has already pointed out, "the right way to do it" in religious behaviour may change diachronically ${ }^{72}$. It seems that during the VII ${ }^{\text {th }}$ century $\mathrm{BC}$, gift items reflecting the newly established relations with other regions of the Mediterranean become more "visible" in cult activities, and these provided opportunities for their owners to display their capacity to import "exotic things" from remote regions ${ }^{73}$. As a consequence, the number and the variety of the gift objects in the sanctuaries greatly increased in this period while the architectural frame for the religious activities was relatively simple and less elaborate.

Another common characteristic between the Heraion of Samos, the Artemision of Ephesos, the Apollon sanctuary in Phanai, the harbour sanctuary of Emporion, and the sanctuary of Athena in Miletos, is that all have revealed archaeological finds dating from the Bronze Age. While the secular nature of the Bronze Age settlement of Chios in Emporio is almost certain, ceramic and terracotta examples that were found in Samos, Ephesos, Chios Phanai, and the altars that were found in the Miletos Athena sanctuary, have been interpreted as evidence of cult activity during the Mycenaean

\footnotetext{
67 Beaumont-Archontidou-Argyri 1999, 272; see also Strab. XXXVI. 43. 11; XLIV. 28. 15 and XLV. 10. 1 for the utilization of the harbour.

68 Beaumont - Archontidou-Argyri 2004, 253.

69 Beaumont - Archontidou-Argyri 2004, 253.

70 Beaumont 2007, 141-143; see also Boardman 1959, 185-186.

71 Eren 2015, 324.

72 Foxhall 1998, 307.

73 See Duplouy 2006, 248-249 for the notion of "mode de reconnaissance social".
} 
Periodin these places ${ }^{74}$. Therefore, in the next section, I focus upon a detailed description of the Bronze Age remains in Ionian sanctuaries in order to investigate if there was a repeated similarity in religious responses to the environment in different periods of Ionian history.

\section{Continuity or Something Else? Bronze Age Remains in these Sanctuaries}

Some of the most monumental sanctuaries of the region have revealed some Bronze Age features, and these traces have often been interpreted as signs of religious continuity. However, detailed investigation of these sanctuaries reveals further ambiguities and it seems important to ask to what extent it was necessary for these developing sanctuary sites in the Archaic period to take into account pre-existing cult places.

In the Artemision of Ephesos, a retaining wall is the only architectural structure dating from the Mycenaean Period. In contrast, ceramic finds from the eastern part of the peripteros and a terracotta head of the Lord of Assine type are among the Bronze Age remains found in the Artemision ${ }^{75}$. All of these finds were excavated from a layer that sits below a bothros and a square base in the central part of the sanctuary. Bammer suggests that these structures appear to be in contact with the Mycenaean remains, and thinks that during the VIII ${ }^{\text {th }}$ century the Mycenaean facilities were converted to serve new functions within the new structure of the sanctuary ${ }^{76}$. However he also admits that there is insufficient evidence to prove continuity of worship during the Sub-Mycenaean and the ProtoGeometric periods. On the other hand, the presence of figurines of cattle, dating from the $\mathrm{XI}^{\text {th }}$ to the VIII $^{\text {th }}$ centuries $\mathrm{BC}$, proves the existence of cult activities at the site beginning with the arrival of the Greeks ${ }^{77}$.

At the Heraion in Samos, the excavators also found the remains of Mycenaean ceramics around the Proto-Geometric altar. The typology of the ceramics suggests a cultic use; however any architectural remains dating from the same era are totally absent. Four fragments of bowls and two terracotta figurines - a bull's head and a human head - are indicators of the Mycenaean presence ${ }^{78}$. Archaeologists also revealed the presence of an altar dating from the Proto-Geometric period ${ }^{79}$. It is likely that a primitive naiskos-like building was built around this altar. Votive finds include wheelmade terracotta figurines of cattle and large female statuettes with their arms raised ${ }^{80}$. Towards the end of the VIII ${ }^{\text {th }}$ century, the number of wheel-made figurines decreases, while handmade terracotta horse figurines constitutes the majority of the finds ${ }^{81}$.

In the sanctuary of Apollo Phanai Chios, the excavators also found Mycenaean pottery with some terracotta figurines from the same period, but all of these finds are from mixed layers that also include Geometric Period ceramics. It is therefore difficult to assign them to well-established stratigraphic layers. However, the excavators believe that this is evidence of cultic continuity extending

74 Niemeier 2005 and Schnapp-Goubeillon 2002, 240-243 display all the evidence from Ionian sanctuaries; see also Niemeier-Niemeier 1997 forthe Miletos Athena sanctuary; Bammer 2004 for the EphesosArtemision and Beaumont - Archontidou-Argyri 2004 for the Apollon Phanai sanctuary on Chios.

75 See Forstenpointer et al. 2008, 38-39 even though these finds belong to a later context.

76 Bammer 1990, 142; 1994, 38.

77 Kerschner 2003, 246.

78 Baumbach 2004, 149.

79 Kyrieleis 1993, 128.

80 Jarosch 1994, 32.

81 Brize 1997, 126. 
from the Bronze Age in Chios ${ }^{82}$.

At Miletos, the Temple of Athena provides a rather interesting example. The "Kultmal" was at the centre of cult activities at this sanctuary from the early VIII ${ }^{\text {th }}$ century. However, the excavations conducted byNiemeier show that this structure has its origins in the Mycenaean period and formed a part of the ramparts built at the end of the Mycenaean Bronze Age ${ }^{83}$. Thus, it is difficult to prove the religious role of this structure in its earliest incarnation, as it was probably related to the defensive system of the city. One should also mention that the zone around the Athena sanctuary was used for a long time for religious activities. The excavations present a group of altars from the late Minoan period, where many terracotta fragments and animal bones dating from the same period were found. The discovery of two terracotta figurines in this area may also indicate religious practices during the Mycenaean period ${ }^{84}$.

To summarise, there are Bronze Age phases at the Samos Heraion, at the Ephesos Artemision, on Chios Apollon Phanai and at the Emporio Harbour sanctuary, and at the Miletos Athena sanctuary. Archaeological evidence also shows the presence of Bronze Age cult activities in the Heraion, Artemison, and Phanai Apollonion, even though the Mycenaean remains at Phanai were found in the Geometric Period layers ${ }^{85}$. On the other hand, noteworthy is the fact that there are long periods of silence between the Bronze Age and the Geometric Period cult activities. In addition, the organization of cult activities in the Geometric Period seems to be completely different from that of its predececessors. Therefore, it is possible to observe a total differentiation in material practice while the number and diversity of sanctuaries clearly increased ${ }^{86}$. Within this context, it is difficult to demonstrate continuous religious activity at these sanctuaries although it is certain that the reuse of Bronze Age sacred places was nonetheless common.

On the other hand, all of this data may demonstrate the existing importance of sea connections in the Western Aegean during the Late Bronze Age. As Greaves has already pointed out, settlements across western Asia Minor appear to be strategically located to take advantage of both landscape features and trade opportunities. Consequently, a connection with the sea seems to be one of the factors which influenced the choice of a settlement location ${ }^{87}$. The existence of many coastal settlements in Bronze Age Asia Minor shows that Western Aegean culture was basically a maritime one, and these cultural roots allow the continuous use of some locations over a long period of time ${ }^{88}$. Consequently, the topographical detail of the landscape seems to have a distinct reflection in religious behaviour as also likewise in economic and social relations ${ }^{89}$.

\section{Conclusions}

In attempting to understand the evolution of culture within a specific region, it is tempting to insist upon a linear evolution; however this tends to result in the oversimplification of a more complicated process. The utilization of the same religious site over a long period of time does not necessarily

82 Beaumont - Archontidou-Argyri 2004, 253.

83 Niemeier - Niemeier 1997, 196; see also Held 2000, 6-14.

84 Niemeier 2005, 13.

85 Beaumont - Archantidou-Argyri 2004, 253.

86 Morgan 1996, 57. This seems to be a general phenomenon in many regions of Greece.

87 Greaves 2010b, 879 .

88 Greaves 2007, 4-5.

89 Horden - Purcell 2000, 459. 
mean that religious activity remained continuous. Over the course of many generations, religious practices often change entirely or more subtly through adapting to the exigencies of different ethnic groups. As Geertz noted, even if one can observe the reflection of fundamental changes in the rituals, the conceptualization of the religious spaces themselves does not change so quickly, because individuals first seek a physical world-place to which they can assign a meaning ${ }^{90}$. Therefore, it seems clear that the religious use of the same place over a long period of time does not necessarily mean that the religious practices that occur there continued to maintain the same meaning.

Indeed, as was pointed out by Horden and Purcell, continuity is directly related to the lack of alternatives within a micro-region ${ }^{91}$. The combination of a good harbour and a fresh water source seems to guarantee the continued use of a location over a long period, especially in a region where the sea and maritime networks are particularly important. The knowledge of a secure bay, probably with drinking water, had to have been very important for sailors, and a sanctuary provides, among other functions, a neutral/open ground for its visitors. Therefore, it is not surprising that a topography of cult with strong links to the Aegean maritime networks developed during this period.

It seems that being linked to sailing networks was a very important feature of many Ionian sanctuaries. Therefore, visibility from the sea seems to have played an important role in determining the location for the establishment of Ionian sanctuaries as is evident in the example of the Aphrodite sanctuary in Miletos. Moreover, if we evaluate the location of the sanctuaries of Hera in Samos, Artemis in Ephesos as also Apollo Phanai in Chios from a topographical-geographical perspective, it is possible to observe that all of these "old" sanctuaries feature safe, well-known and well frequented harbours and natural water sources.

Another common element that all these sanctuaries share is a wide variety of votive gifts originating from different parts of the Mediterranean. This is often interpreted as evidence of their engagement with the Aegean sailing networks ${ }^{92}$. However, this kind of integration into the Mediterranean maritime networks functioned differently for the various Ionian cities and on different levels. Sometimes, such integration required the organization of intermediate spaces to assure contact with the outside world. The architecture and the diversity of the votive gifts show that these sanctuaries were essentially independent zones that welcomed visitors coming from the sea ${ }^{93}$.

In this context, if we evaluate important Ionian sanctuaries as "accessible" zones that provide shelter to sailors in hostile sailing conditions, we can also argue that towards the end of the Archaic Period their position within Ionia began to change as they become more "integrated" into the new concepts of spatial organization, which emphasized the growing importance of the city centre within the city's territory. In most cases, entrances oriented to the sea were closed off and new access points were added, which were oriented to the newly established sacred roads that linked important Ionian sanctuaries with the city centres. Therefore, with the addition of the newly established sacred processions, it is possible to observe that the relationship of the sanctuaries to the city's territory was more emphasized than the sanctuaries connections with the sea. The sanctuaries of Hera on Samos and Apollon at Didyma appear to reflect this transformation better than any other examples in

90 Geertz 1993, 143.

91 Horden - Purcell 2000, 411.

92 Saint-Pierre 2005 provides a very detailed panorama of the "Oriental" gifts in the sanctuaries; see also Polignac 1997; Etienne 2010, 249-269.

93 Eren 2015, 324. 
Ionia. While the entrance from the sea to the Samos Heraion was sealed somewhere between the end of the VII ${ }^{\text {th }}$ or in the beginning of the VI ${ }^{\text {th }}$ century, the importance of the newly established sacred road increased from the beginning of the $\mathrm{VI}^{\text {th }}$ century and it seems earlier monumental kouroi were relocated to be related and re-integrated with this new axis ${ }^{94}$. On the other hand, in Miletos, the Didyma Apollon sanctuary seems to be linked to the Apollon Delphinios sanctuary which was situated in the centre of the city via a sacred road, which was probably emphasised through the positioning along it of statues of seated men and women ${ }^{95}$.

One can also suggest that while it is the case that the variety and the number of votive objects diminished, the architecture becomes more monumentalized ${ }^{96}$. According to Morgan, although the VIII ${ }^{\text {th }}$ century is considered the period when sanctuaries were first established, creating a more uniform concept of temples seems to be a phenomenon of the late $\mathrm{VII}^{\text {th }}$ and $\mathrm{VI}^{\text {th }}$ centuries $^{97}$. Similarly, the diversity and richness of the offerings then degrades towards an accentuated standardization, and accordingly, terracotta figurines that display the iconography of the local deity then becomes the most common gift object in the sanctuaries ${ }^{98}$. Thus, it is important to point out that architectural monumentalization seems to reflect a new phase in the structuring of space, linked to the emergence of new social hierarchies.

It appears that the "imaginary map" of the polis territory and the specific roles of the city's pantheon become more clear and regularized ${ }^{99}$. The crystallization of the relationship between centre and periphery, and the homogenization of city space towards the end of the Archaic period present a new and more hierarchical model of spatial organization.

To conclude, it is evident that the orientation of a sanctuary to 'its city' continued to change and evolve over the course of its long life as a sacred area - building. The balance between local history and geography is particularly important for understanding the long-term strategies of these everevolving religious sanctuaries-buildings. It is therefore important to form an understanding of the locations of sanctuaries that does not solely rely upon an analysis that defines them in relation to their urban context, but instead integrates them into a broader framework. In all cases, the study of urbanization must be multifaceted, and any formal analysis of space is insufficient, as one needs to evaluate all of the parametres that can influence the selection of location for the establishment of places of worship.

94 Duplouy 2006, 190-193; see also Kyrieleis 1993, 130.

95 See Duplouy 2006, 203-210 for an evaluation of the position of these statues.

96 Polignac 1997, 120.

97 Morgan 2003, 108.

98 See also Kurke 1999, 117. The author interprets the first striking of coinage as a sign of a newly established civic community.

99 Etienne $(2004,38)$ proposes a very similar vision for $\mathrm{VI}^{\text {th }}$ century Athens. 


\section{BIBLIYOGRAPHY}

\section{Ancient Sources}

Hdt.

(= Herodotus, Historiae)

The Persian Wars, vols. I-IV. Trans. A. D. Godley. Cambridge, Massachusetts - London 1920-2004 ${ }^{12}$ (The Loeb Classical Library).

Paus. (= Pausanias, Periegesis tes Hellados)

Description of Greece, vols. I-IV. Trans. W. H. Jones, H. A. Ormerod - R. E. Wycherley. New York 1918-2004 ${ }^{10}$ (The Loeb Classical Library).

Strab. (= Strabon, Geographika)

The Geography of Strabo, vols. I-VIII. Trans. H. L. Jones. London - New York 1917-1932 (The Loeb Classical Library).

Strabon, Coğrafya. Trans. A. Pekman. İstanbul 2000.

\section{Modern Literature}

Akurgal 1979

E. Akurgal, Erythrai. An Ancient Ionian City. İzmir 1979.

Bammer 1990

A. Bammer, "A Peripteros of the Geometric Period in the Artemision of Ephesus”. AnatSt 40 (1990) 137-160.

Bammer 1991

A. Bammer, "Les Sanctuaires de VIII et VIIe siècles à l'Artémision d'Éphèse”. RA (1991) 63-84.

Bammer 1991/1992

A. Bammer, "Multikulturelle Aspekte der frühen Kunstim Artemision von Ephesos”. Öjh 61(1991/1992) 17-54.

Bammer 1993

A. Bammer, "Fouilles à l'Artémision d'Éphèse (Période Géometrique et Archaique): Nouvelles Données”. RA (1993) 187-199.

Bammer 1994

A. Bammer, "Geschichte neu geshrieben: Mykene im Artemision von Ephesos". Öjh 63 (1994) 29-40.

Bammer 1998 A. Bammer, "Sanctuaries in the Artemision of Ephesus". Ed. R. Hagg, Ancient Greek Cult Practice from the Archaeological Evidence. Stockholm (1998) 27-47.

Bammer 2004

A. Bammer, "Mykene und der Ephesische Peripteros". Ed. M. Fano Santi, Studi di Archeologia in Onore di Gustavo Traversari. Rome (2004) 29-45.

Baumbach 2004

J. D. Baumbach, The Significance of Votive Offerings in Selected Hera Sanctuaries in the Peloponesse, Ionia and Western Greece. Oxford 2004.

Bayburtluoğlu 1977

C. Bayburtluoğlu, Erythrai II, PişmişToprak Eserler. Ankara 1977.

Beaumont - Archontidou-Argyri 1999

L. A. Beaumont - A. Archontidou-Argyri, "New Work at Kato Phana, Chios: The Kato Phana Archaeological Project”. BSA 94 (1999) 265-287.

Beaumont - Archontidou-Argyri 2004

L. A. Beaumont - A. Archontidou-Argyri, "Excavations at Kato Phana, Chios: 1999, 2000, and 2001”. BSA 99 (2004) 201-255.

Beaumont 2007

L. A. Beaumont, "Chios: The Kato Phana Archaeological Project". Eds. J. Cobbet, V. Von, Graeve, W. D. Niemeier - K. Zimmermann, Frühes Ionien. Eine Bestandsaufnahme. Mainz am Rhein (2007) 137-148.

Boardman 1959

J. Boardman, "Chian and Early Ionic Architecture". Antiquaries Journal 39 (1959) 170-218. 
Boardman 1967

Brize 1997

. Boardman, Excavations in Chios, 1952-1955: Greek Emporio. London 1967.

P. Brize, "Offrandes de l'Epoque Géométrique et Archaïque à l'Héraion de Samos" Ed. J. de la Genière, Héra: Images, Espaces, Cultes. Naples (1997) 123-139.

Bruit-Zaidmann - Schmitt-Pantel 1999

L. Bruit-Zaidmann - P. Schmitt-Pantel, La religion grecque dans les cités à l'époque classique. Paris 1999.

Buschlor - Scleif 1933

E. Buschlor - H. Scleif, "Heraion von Samos: Der Altarplatz der Frühzeit”. MDAI(A) 58 (1933) 146-173.

Coldstream 1985

J. N. Coldstream, “Greek Temples: Why and Where?". Eds. P. E Easterling - J. V. Muir, Greek Religion and Society. Cambridge (1985) 67-97.

Duplouy 2006

Eren 2012

Eren 2015

Etienne 2004

Etienne 2010

Forstenpointner et al. 2008

Foxhall 1998

Gans 1991

Geertz 1993

Gerkan 1915

Greaves 2000a

Greaves 2000b

Greaves 2004

Greaves 2007

Greaves 2010a

Greaves 2010b

Guettel-Cole 1988
A. Duplouy, Le Prestige des Elites. Paris 2006.

K. Eren, "Samos Heraion ve Ephesos Artemis Kutsal Alanlarındaki Oryantal Objeler". MJH 2/1 (2012) 87-95.

K. Eren, "Ionian Sanctuaries and the Mediterranean World in the Seventh-Century B.C.". Eds. P. M. Militello - H. Öniz, Proceedings of the $15^{\text {th }}$ Symposium on Mediterranean Archaeology, vol. 1. Oxford (2015) 321-327.

R. Etienne, Athènes, espaces urbains, et histoire. Paris 2004.

R. Etienne, La Méditerranée au VIIe s. av. J.-C. Paris 2010.

G. Forstenpointner, M. Kerschner, U. Muss, "Das Artemision in der spaten Bronzezeit und der frühen Eisenzeit”. Ed. U. Muss, Die Archaeologie der ephesischen Artemis. Wien (2008) 33-46.

L. Foxhall, "Cargoes of the Heart's Desire. The Character of Trade in the Archaic Mediterranean World". Eds. N. Fisher - H. wan Wees, Archaic Greece. New Approaches and New Evidence. Swansea (1998) 295-309.

U. Gans, "Die Grabung auf dem Zeytintepe". IstMitt 41 (1991) 137-140.

C. Geertz, The Interpretation of Cultures. London 1993.

A. von Gerkan, Der Poseidonaltar bei Kap Monodendri. Berlin 1915.

A. M. Greaves, "Miletos and the Sea: A Stormy Relationship". Ed. G. J. Oliver, The Sea in Antiquity. Oxford (2000) 39-62.

A. M. Greaves, "The Shifting Focus of Settlement at Miletus". Ed. P. Flensted-Jensen, Further Studies in Ancient Greek Polis. Stuttgart (2000) 57-72.

A. M. Greaves, "The Cult of Aphrodite in Miletos and its Colonies". AnatSt 54 (2004) 27-33.

A. M. Greaves, "Trans-Anatolia: Examining Turkey as a Bridge between East and West". AnatSt 57 (2007) 1-15.

A. M. Greaves, The Land of Ionia. West Sussex 2010.

A. M. Greaves, "Western Anatolia". Ed. E. H. Cline, The Oxford Handbook of the Bronze Age Aegean (ca. 3000-1000 BC). Oxford (2010) 877-879.

S. Guettel-Cole, "The Uses of Water in Greek Sanctuaries". Eds. R. Hagg, N. Marinatos - G. C. Nordquist, Early Greek Cult Practise. Stockholm (1988) 161-165. 
28

Gültekin 1968

Held 2000

Herda 2005

Herda 2006

Horden - Purcell 2000

Jarosch 1994

Kerschner - Senff 1997

Kerschner 2003

Kerschner 2008

Kraft et al. 2000

Kurke 1999

Kyrieleis 1993

Mallwitz 1981

Morgan - Coulton 1997

Morgan 1996

Morgan 2003

Niemeier - Niemeier 1997

Niemeier 1999

Niemeier 2005

Özyiğit - Erdoğan 2000

Özyiğit 1995

\section{Kenan EREN}

H. Gültekin, "Erythrae Kazısında Bulunan Fayans Figürinler". Türk AD 17 (1968) 101-116.

W. Held, Das Heiligtum der Athena in Milet. Mainz am Rhein 2000.

A. Herda, "Apollon Delphinion, das Prytaneion und die Agora von Milet". AA 1 (2005) 243-294.

A. Herda, Der Apollon-Delphinios-Kult in Milet und die Neujahrsprozession nach Didyma. Mainz am Rhein 2006.

P. Horden - N. Purcell, The Corrupting Sea. Oxford 2000.

V. Jarosch, Samische Tonfiguren des 10. bis 7. Jahrhunderts v. Chr aus dem Heraion von Samos. Bonn 1994.

M. Kerschner - R. Senff, "Die Ostterrasse des Kalabaktepe". AA (1997) 120-122.

M. Kerschner, "Zum Kult im früheisenzeitlichen Ephesos. Interpretation eines protogeometrischen Fund komplexes aus dem Artemis heiligtum”. Eds. B. Schmaltz - M. Söldner, Griechische Keramik im kulturellen Kontext. Münster (2003) 246-250.

M. Kerschner, "Die Lyder und das Artemision von Ephesos". Ed. U. Muss, Die Archaologie der Ephesischen Artemis. Wien (2008) 223-233.

J. C. Kraft, İ. Kayan, H. Brückner - G. Rapp, “A Geologic Analysis of Ancient Landscapes and the Harbours of Ephesus and the Artemision in Anatolia”. Öjh 69 (2000) 175-232.

L. Kurke, Coins, Bodies, Games, and Gold. The Politics of Meaning in Archaic Greece. Princeton 1999.

H. Kyrieleis, "The Heraion at Samos". Eds. N. Marinatos - R. Hagg, Greek Sanctuaries New Approaches. London - New York (1993) 125-153.

A. Mallwitz, "Kritisches zur Architektur Griechenlands im 8. Und 7. Jahrhundert". AA (1981) 599-642.

C. Morgan - J. J. Coulton, "The Polis as a PhysicalEntity". Ed. M. H. Hansen, The Polis as an Urban Centreand as a Political Community. Copenhagen (1997) 87-144.

C. Morgan, "From Palace to Polis? Religious Developments on the Greek Mainland During the Bronze Age/Iron Age Transition”. Eds. P. Hellström - B. Alroth, Religion and Power in the Ancient Greek World. Uppsala (1996) 41-57.

C. Morgan, Early Greek States Beyond the Polis. London - New York 2003.

B. Niemeier - W. D. Niemeier, "Milet 1994-5 Projekt 'Minoisch-Mykenisches bis Protogeometrisches Milet': Zielsetsung und Grabungen auf dem Stadionhügel und am Athenatempel”. AA (1997) 189-248.

W. D. Niemeier, “Die Zierde Ioniens”. AA (1999) 374-409.

W. D. Niemeier, "Minoans, Myceneans, Hittites and Ionians in Western Asia Minor”. Ed. A. Villing, The Greeks in the East. London (2005) 1-36. Ö. Özyiğit - A. Erdoğan, "Les Sanctuaires de Phocée à la lumiere des dernieres fouilles". Eds. A. Hermary - H. Treziny, Les cultes des cités Phocéennes. Aix-en-Provence (2000) 11-23.

Ö. Özyiğit,"1994 Yılı Phokaia Kazı Çalışmaları”. KST 17/2 (1995) 1-26. 
Polignac 1984

Polignac 1994

Polignac $1995^{2}$

Polignac 1997

Roebuck 1959

Rupp 1983

Saint-Pierre 2005

Schnapp-Gourbeillon 2002

Scully 1963

Senff - Heinz 1997

Senff 2003

Senff 2006

Simon 1997

Sourvinou-Inwood 1993

Treziny 2006

Walter 1990
F. de Polignac, La naissance de la cité grecque. Paris 1984.

F. de Polignac, "Mediation, Competition, and Sovereignity: The Evolution of Rural Sanctuaries in Geometric Grece”. Eds. S. E. Alcock - R. Osborne, Placing the Gods. Sanctuaries and Sacred Space in Ancient Greece. Oxford (1994) 3-18.

F. de Polignac, La naissance de la cité Grecque. Paris $1995^{2}$.

F. de Polignac, "Héra, le navire et la demeure: offrandes, divinité et société en Grèce archaique". Ed. J. de la Genière, Héra: Images, Espaces, Cultes. Naples (1997) 113-122.

C. Roebuck, Ionian Trade and Colonization. New York 1959.

D. W. Rupp, "Reflections on the Development of Altars in the Eight Century B.C.”. Ed. R. Hagg, The Greek Renaissance of the Eight Centuries B.C.: Tradition and Innovation. Stockholm (1983) 101-107.

C. Saint-Pierre, Les offrandes orientales dans les sanctuaires $d u$ monde grec à l'époque archaïque. Unpublished Doctoral Dissertation, Université Paris. Paris. 2005.

A. Schnapp-Gourbeillon, Aux Origines de la Grèce. Paris 2002.

V. Scully, The Earth, the Temple, and the Gods: Greek Sacred Architecture. London - New Haven 1963.

R. Senf - M. Heinz, “Arbeiten am Zeytintepe im Jahre 1994". AA (1997) 114-117.

R. Senff, "Das Aphroditeheiligtum von Milet". Asia Minor Studien 49 (2003) 11-25.

R. Senff, "Form and Function of Sanctuaries in Archaic Miletos". REA 108 (2006) 159-172.

C. G. Simon, "The Archaeology of Cult in Geometric Greece. Ionian Temples, Altars and Dedications". Ed. S. Langdon, New Light on a Dark Age. Columbia (1997) 125-143.

C. Sourvinou-Inwood, "Early Sanctuaries, the Eight Century and Ritual Space: Fragments of a Discourse". Eds. N. Marinatos - R. Hagg, Greek Sanctuaries. New Approaches. London - New York (1993) 1-17.

H. Treziny, "Urbanisme Archaique des villes Ioniennes: Un Point de vue Occidental". REA 108 (2006) 225-247.

H. Walter, Das Griechische Heiligtum dargestellt am Heraion von Samos. Stuttgart 1990. 
